\title{
Risk factors in an association with the osteoarthritis of the knee in Mosul city
}

\author{
Yakdhan Z. Alsaleem \\ From the Department of Surgery, College of Medicine, University of Mosul. \\ Correspondence: Yakdhan Z. Alsaleem. Lecturer, Department of Surgery, College of Medicine, University of Mosul, Mosul, \\ Iraq. Email: alsaleem_y@yahoo.com.
}

(Ann Coll Med Mosul 2013; 39 (1): 84-88).

Received: $20^{\text {th }}$ Mar. 2012; Accepted: $13^{\text {th }}$ Jan. 2013.

\section{ABSTRACT}

Background: Osteoarthritis of knee is a common cause of pain and disability. It is becoming increasingly prevalent worldwide due to its association with an aging and obesity.

Objective: The aim of this study was to examine the associations between body mass index, gender, Islamic praying, praying in sitting position, usage of stairs, history of traumas, diabetes, hypertension, and hypothyroidism as risk factors for knee osteoarthritis in population of Mosul city.

Patients and methods: This study is a case - control design, it was conducted through the period from Jan 2010 - Jan 2011 in the orthopedic outpatient clinic of Aljumhoori Teaching Hospital in Mosul. The target population of this study consisted of 213,71 cases (61 females, 10 males), their ages mean 51.77 years, and 142 as controls.

Results: The body mass index was higher in cases and shows highly significant difference between cases and control $(p \leq 0.000)$. Sex distribution in knee osteoarthritis revealed that there was significant difference between females and males as cases of osteoarthritis, $(P \leq 0.0001)$. Normal Islamic praying, Praying in sitting position, usage of stairs, appeared to be an associated risk factors, history of trauma was significantly higher in cases, while diabetes, hypertension, and hypothyroidism was not associated with the development of osteoarthritis of the knee.

Conclusion: Females as a gender, obesity, Islamic praying in sitting position and history of trauma to the knee are important risk factors of osteoarthritis of the knee, while diabetes, hypertension and hypothyroidism are not associated with knee osteoarthritis.

Keywords: Osteoarthritis, knee, risk factors.

\section{عوامل الخطورة المرتبطة مع سوفان الركبة في مدينة الموصل}

الخلفية: سوفان مفصل الركبة هو مسبب أساسي وشائع للألم وتدني الكفاءة والقدرة على العمل وهو شائع في كل أرجاء العالم

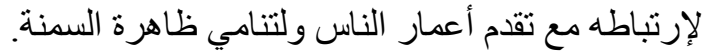
الأهداف: هدف الدر اسة هو معرفة الترابط بين الجنس، السمنة، الصلاة الإسلامية المعتادة وفي وضع الجلوس والإصـابات السابقة

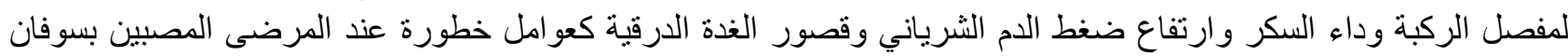

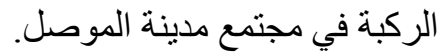

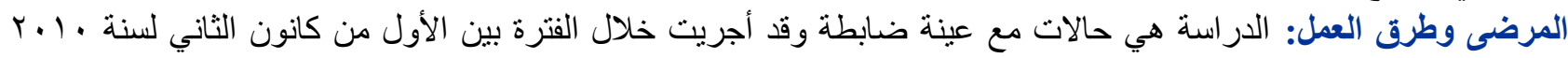

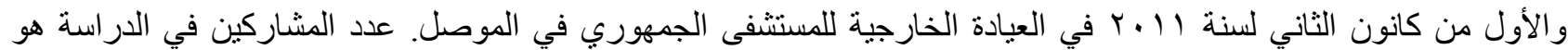

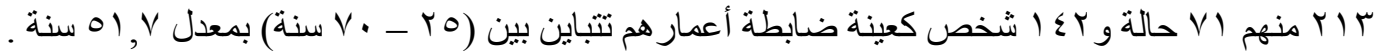

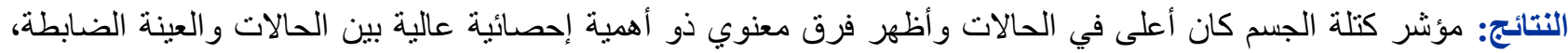

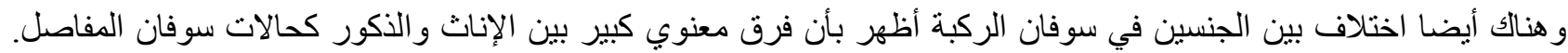

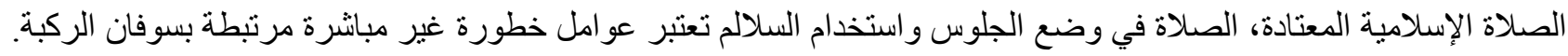


الإصابات السابقة أظهرت فرقا معنويا لدى الحالات. بينما كان داء السكر وإرتفاع ضغط الدم الثرياني وقصور الغدة الدرقية لايرتبطون بتقدم سوفان الركبة.

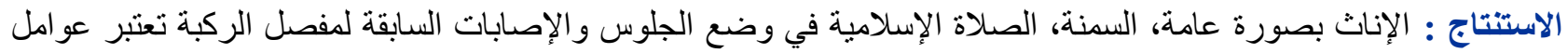

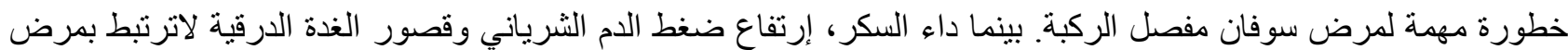

$\mathrm{O}$ steoarthritis, is a common major contributor to functional impairment, it is becoming increasingly prevalent worldwide due to its association with an aging population and due to a growing prevalence of obesity. Knee osteoarthritis is a common cause of pain and disability ${ }^{(1,2)}$. While age is strongly associated with the risk of knee osteoarthritis; overweight is important modifiable risk factor ${ }^{(1,2)}$, body mass index (BMI) has been associated with the incidence and progression of knee osteoarthritis, independently of age and sex. Even a moderate increase in BMI, within the normal range, was shown to be significantly related to knee osteoarthritis ${ }^{(1,2)}$. About one-third of all adults have radiological signs of osteoarthritis. Knee osteoarthritis was the most common type of osteoarthritis ${ }^{(3)}$. The radiological demonstration of typical signs of osteoarthritis of the knee is not correlated with symptoms. A recent World Health Organization report on the global burden of disease indicates that knee $O A$ is likely to become the fourth most important cause of disability in women, and the eighth most important cause in men ${ }^{(4)}$.

The aim of this study was to examine the associations between gender, BMI, normal Islamic praying, praying in sitting position, history of trauma, using of stairs, and medical history of diabetes mellitus, hypertension and hypothyroidism as a risk factors for knee osteoarthritis in population of Mosul city.

\section{PATIENTS AND METHODS}

This study was approved by the scientific committee at the College of Medicine, University of Mosul. Informed consent was signed by all the individuals who accepted participation in the study. The study was conducted through the period $1^{\text {st }}$ Jan 2010-1 ${ }^{\text {st }}$ Jan 2011 at the orthopedic outpatient clinic of Aljumhoori Teaching Hospital in Mosul. The target population of this study consisted of 213. Seventy one cases met the inclusion criteria of knee osteoarthritis ${ }^{(5)}$, their ages ranged between (25-70 years) with average 51.77 years, (61 females, 10 males). The control group was 142 (66 male and 76 female), the sample of control was selected according to the method of individual matching ${ }^{(6,7)}$. For each patient with osteoarthritis of the knee two controls was chosen. The criteria for control group selection were; person suffering from any disease other than osteoarthritis of the knee admitted to the same outpatient clinic of the hospital next to the osteoarthritis. We categorized BMl into groups according to the classification of overweight and obesity by body mass index ${ }^{(8)}$.

Demographic data were recorded using standardized data sheet.

All participant patients had radiographic examination of both knees using an anterior, posterior and lateral view with weight-bearing. Knee radiographs were read without knowledge of participant clinical status by a single wellexperienced radiologist ${ }^{(5)}$.

Statistical analysis was conducted using Chisquared $\left(x^{2}\right)$ test, $2 \times 2$ table, and $95 \%$ confidence interval. $P$-values $<0.05$ were considered significant ${ }^{(7)}$.

\section{RESULTS}

The patients gender revealed that there was significant difference between females (61 patients) and males (10 patients) while in control group there was 66 male and 76 female, by Chi square test $(P \leq 0.0001)$, (Table 1).

BMI distributions shows that knee OA more in overweight (25-29.9) and obese (30-34.9) patients in comparison with control, by using Chi square test there was a highly significant difference $P \leq$ 0.000, (Table 2).

Table 1. Sex distribution for both cases and controls.

\begin{tabular}{|l|c|c|c|c|}
\hline \multicolumn{1}{|c|}{ Sex } & $\begin{array}{c}\text { No. } \\
\text { Cases }\end{array}$ & $\%$ & $\begin{array}{c}\text { No. } \\
\text { Controls }\end{array}$ & $\%$ \\
\hline No. Males & 10 & 14 & 66 & 46 \\
\hline No. Females & 61 & 86 & 76 & 54 \\
\hline Totals & 71 & 100 & 142 & 100 \\
\hline
\end{tabular}

$X^{2}=21.6 . P \leq 0.000$. 
Table 3 shows the distribution of cases and controls according to the daily life activities, reveals that usage of high stairs appeared to be an associated risk factor for osteoarthritis of the knee, it highly significant $P \leq 0.000$, the same thing applied for normal Islamic praying $P$ value 0.006 , $\mathrm{OR}=0.432$. Finally praying in sitting position appeared to be an associated risk factor with (O R $=2.05, \mathrm{P} \leq 0.014,95 \% \mathrm{Cl} 1.1-3.6)$.

Table 4 indicates that history of trauma to the affected knee is associated risk factor and appeared to be highly significant factor $P \leq 0.000$, while diabetes, hypertension, and hypothyroidism were not associated with the development of osteoarthritis of the knee. The radiological findings in cases show significant changes in comparison with control, (Table 5).

Table 2. Body mass index distributions in different groups.

\begin{tabular}{|l|c|c|c|c|}
\hline \multicolumn{1}{|c|}{ B M I } & No. cases & $\%$ & $\begin{array}{c}\text { No. } \\
\text { controls }\end{array}$ & $\%$ \\
\hline $18.5-24.9$ & 5 & 7 & 59 & 41.5 \\
\hline $25-29.9$ & 14 & 20 & 41 & 29 \\
\hline $30-34.9$ & 24 & 34 & 32 & 22.5 \\
\hline $35-39.9$ & 15 & 21 & 8 & 6 \\
\hline$>40$ & 13 & 18 & 2 & 1 \\
\hline Total & 71 & 100 & 142 & 100 \\
\hline
\end{tabular}

Table 3. The association of daily life activities as a risk factor for developing osteoarthritis of the knee.

\begin{tabular}{|c|c|c|c|c|c|c|c|c|}
\hline \multirow{2}{*}{ Daily life } & \multicolumn{2}{|c|}{ Cases (No.=71) } & \multicolumn{2}{|c|}{ Control $($ No. $=142)$} & \multirow{2}{*}{$x^{2}$} & \multirow{2}{*}{$P$ value } & \multirow{2}{*}{ OR } & \multirow{2}{*}{95 \% C.I. } \\
\hline & No. & $\%$ & No. & $\%$ & & & & \\
\hline \multirow{2}{*}{ Usage of stairs } & 37 & 52 & 118 & 83 & \multirow{2}{*}{21.398} & \multirow{2}{*}{0.000} & \multirow{2}{*}{0.221} & \multirow{2}{*}{$0.117-0.480$} \\
\hline & 34 & 48 & 24 & 17 & & & & \\
\hline \multirow{2}{*}{$\begin{array}{l}\text { Normal Islamic } \\
\text { praying }\end{array}$} & 26 & 37 & 82 & 58 & \multirow{2}{*}{7.628} & \multirow{2}{*}{0.006} & \multirow{2}{*}{0.423} & \multirow{2}{*}{$0.236-0.758$} \\
\hline & 45 & 63 & 60 & 42 & & & & \\
\hline \multirow{2}{*}{ praying sitting } & 38 & 54 & 51 & 36 & \multirow{2}{*}{5.329} & \multirow{2}{*}{0.014} & \multirow{2}{*}{2.055} & \multirow{2}{*}{$1.155-3.656$} \\
\hline & 33 & 46 & 142 & 64 & & & & \\
\hline
\end{tabular}

Table 4. The association of past medical history as a risk factor for developing osteoarthritis of the knee.

\begin{tabular}{|c|c|c|c|c|c|c|c|c|}
\hline \multirow{2}{*}{$\begin{array}{l}\text { Past medical } \\
\text { history factors }\end{array}$} & \multicolumn{2}{|c|}{ Cases (No.=71) } & \multicolumn{2}{|c|}{ Control (No. $=142)$} & \multirow{2}{*}{$x^{2}$} & \multirow{2}{*}{$P$ value } & \multirow{2}{*}{ OR } & \multirow{2}{*}{$95 \%$ C.I. } \\
\hline & $\%$ & No. & $\%$ & No. & & & & \\
\hline \multirow{2}{*}{ Diabetes } & 11 & 8 & 21 & 30 & \multirow{2}{*}{2.502} & \multirow{2}{*}{0.114} & \multirow{2}{*}{0.47} & \multirow{2}{*}{$0.209-1.080$} \\
\hline & 89 & 63 & 79 & 112 & & & & \\
\hline \multirow{2}{*}{ Hypertension } & 38 & 27 & 39 & 55 & \multirow{2}{*}{0.000} & \multirow{2}{*}{1.000} & \multirow{2}{*}{0.971} & \multirow{2}{*}{$0.542-1.739$} \\
\hline & 62 & 44 & 61 & 87 & & & & \\
\hline \multirow{2}{*}{ Trauma } & 7 & 5 & 59 & 84 & \multirow{2}{*}{50.845} & \multirow{2}{*}{0.000} & \multirow{2}{*}{0.052} & \multirow{2}{*}{$0.020-0.134$} \\
\hline & 93 & 66 & 41 & 58 & & & & \\
\hline \multirow{2}{*}{ Hypothyroidism } & 1 & 1 & 1 & 1 & \multirow{2}{*}{0.000} & \multirow{2}{*}{1.000} & \multirow{2}{*}{0.000} & \multirow{2}{*}{$0.000-7.731$} \\
\hline & 99 & 70 & 99 & 141 & & & & \\
\hline
\end{tabular}

Table 5. The association of radiological findings in patients and control in antro-posterior and lateral views of the knee.

\begin{tabular}{|c|c|c|c|c|c|c|c|c|}
\hline \multirow{3}{*}{ Factor } & \multicolumn{8}{|c|}{ Radiological appearance A P ( Proper knee) } \\
\hline & \multicolumn{2}{|c|}{ Cases (No.=71) } & \multicolumn{2}{|c|}{ Control (No.=142) } & \multirow{2}{*}{$x^{2}$} & \multirow{2}{*}{$P$ value } & \multirow{2}{*}{ OR } & \multirow{2}{*}{95 \% C.I. } \\
\hline & $\%$ & No. & $\%$ & No. & & & & \\
\hline \multirow{2}{*}{$\begin{array}{l}\text { Osteophyte } \\
\text { appearance }\end{array}$} & 38 & 27 & 25 & 36 & \multirow{2}{*}{3.068} & \multirow{2}{*}{0.080} & \multirow{2}{*}{1.807} & \multirow{2}{*}{$0.985-3.316$} \\
\hline & 62 & 44 & 75 & 106 & & & & \\
\hline \multirow{2}{*}{ Joint narrowing } & 44 & 31 & 40 & 57 & \multirow{2}{*}{0.119} & \multirow{2}{*}{0.731} & \multirow{2}{*}{1.156} & \multirow{2}{*}{$0.651-2.052$} \\
\hline & 56 & 40 & 60 & 85 & & & & \\
\hline \multirow{2}{*}{ Sclerosis } & 30 & 21 & 20 & 29 & \multirow{2}{*}{1.728} & \multirow{2}{*}{0.189} & \multirow{2}{*}{1.637} & \multirow{2}{*}{$0.857-3.129$} \\
\hline & 70 & 50 & 80 & 113 & & & & \\
\hline \multirow{2}{*}{ Subchondral cyst } & 6 & 4 & 2 & 3 & \multirow{2}{*}{0.905} & \multirow{2}{*}{1.342} & \multirow{2}{*}{2.766} & \multirow{2}{*}{$0.672-11.367$} \\
\hline & 94 & 67 & 98 & 139 & & & & \\
\hline Factor & \multicolumn{8}{|c|}{ Radiological appearance lateral (Patellofemoral) } \\
\hline \multirow{2}{*}{ Narrowing } & 31 & 22 & 19 & 27 & \multirow{2}{*}{3.184} & \multirow{2}{*}{0.074} & \multirow{2}{*}{1.912} & \multirow{2}{*}{$0.999-3.663$} \\
\hline & 69 & 49 & 81 & 115 & & & & \\
\hline \multirow{2}{*}{ Osteophyte } & 37 & 26 & 13 & 19 & \multirow{2}{*}{13.978} & \multirow{2}{*}{0.000} & 2710 & 10007200 \\
\hline & 63 & 45 & 87 & 123 & & & 3.140 & $1.900-1.363$ \\
\hline
\end{tabular}




\section{DISCUSSION}

In the present study, increase in body mass index is strongly associated with the development of the osteoarthritis of the knee. Obesity among adult Populations range from 15 to $60 \%$, which is more common in women than in men. Overweight is associated with increases in the forces across weight-bearing joints and associated with increase in knee osteoarthritis ${ }^{(1,2,8-11)}$. In the present study the gender was important risk factor for knee OA, in our community the women subjected to high physical stress in house hold activities and child bearing.

In another study there was general agreement that females were more likely to develop knee problems than males, we think that females subjected to more stress in house hold activities and children bearing ${ }^{(8,10,12)}$. The combination of intense exposure to heavy work of varied nature and repeated local stresses, especially at a young age, could contribute to some systemic mechanism in the development of $O A^{(13,14)}$.

In the present study the daily life activities reveals that the usage of high stairs appeared to be indirectly an associated risk factor for osteoarthritis of the knee. The normal Islamic praying and praying in sitting position appeared to be indirectly another associated risk factors for osteoarthritis of the knee, these findings might be explained by the excessive pressure on articular pressure during extreme flexion. Regular practice of praying including Kneeling and standing many times a day since childhood may result in more strength and flexibility of soft tissue the knee as well as juxta-articular bone remodeling to prevent micro trauma from repetitive kneeling ${ }^{(12)}$, this ideas is in contrary to our finding.

In the present study the history of trauma to the affected knee is associated risk factor this might be explained by the damage occurred on the articular cartilage and underling bones. One paper investigated effects of jobs requiring knee excessive bending found to be a significant risk factor $^{(12)}$. In the present study the history of systemic diseases like diabetes, hypertension, and hypothyroidism had no effect on the causation of osteoarthritis of the knee. The radiological features in antro-posterior and lateral views of knee including osteophyte formation, narrowing of joint space, subchondral sclerosis and cystic changes show significant difference in patients when compared with control group.

We conclude that osteoarthritis of knee is significantly more in females, in higher body mass index, patients practicing normal Islamic praying and praying in sitting position indirectly risk factors and history of trauma are an important risk factors of osteoarthritis of the knee, while diabetes, hypertension and hypothyroidism are not associated with knee osteoarthritis in our community.

\section{REFERENCES}

1. Lee $\mathrm{J} H$, Song $S H$, Yong $H$, et al. Known Risk Factors of the Symptomatic Knee Osteoarthritis in Koreans: A Population-Based Cross-Sectional Study. International Medical Journal 2010; 17(2): 87 - 93.

2. Vrezas I, Elsner G, Bolm-Audorff U, Abolmaali N, Seidler A. Case-control study of knee osteoarthritis and lifestyle factors considering their interaction with physical workload. Int Arch Occup Environ Health 2010;83:291300.

3. Michael JW, Schlüter-Brust KU, Eysel $P$, Aerzteblatt D. The epidemiology, etiology, diagnosis, and treatment of osteoarthritis of the knee. Dtsch Arztbel International 2010;9(107):152-162.

4. Cooper C, Snow S, Timothy E, et al. Risk Factors For The Incidence And Progression Of Radiographic Knee Osteoarthritis. Arthritis \& Rheumatism 2000;5(43):9951000.

5. Horvath G, Koroknai G, Aes B, Than P, Bellyei A, Illés $T$. Prevalence of radiographic primary hip and kneeosteoarthritis in a representative Central European population. International Orthopaedics (SICOT) 2011; 35:971-975.

6. MacMahon B, Pugh T F. Case control studies. Epidemiology principles and methods. $1^{\text {st }} \mathrm{Ed}$. Boston (USA): Little Brown; 1970. p. 241-282.

7. Kirkwood B R. Essentials of medical statistics. $1^{\text {st }}$ ed. Oxford (UK): Black-Well Scientific Publications; 1988. p.234.

8. Urquhart D M, Soufan C, Teichtahl A J, Wluka A E, Hanna F, Cicuttini F M. Factors that may mediate the relationship between physical activity and the risk for developing knee osteoarthritis. Arthritis Research \& Therapy 2008; 10:203.

9. Toivanen A T, Heliovaara M, Impivaara $O$, et al. Obesity, physically demanding work and traumatic knee injury are major risk factors for knee osteoarthritis-a population-based study with a follow-up of 22 years. Rheumatology 2010; 49:308-314.

10. Blagojevicy $M$, Jinksy $C$, Jefferyz $A$, Jordany $K P$. Risk factors for onset of osteoarthritis of the knee in older adults: a systematic review and meta-analysis. Osteoarthritis and Cartilage 2010; 18: 24-33.

11. Riyazi N, Rosendaal FR, Slagboom E, Kroon HM, Breedveld FC, Kloppenburg M. Risk factors in familial osteoarthritis: the GARP sibling study. Osteoarthritis and Cartilage 2008; 16 (6): 654-659. 
12. Chokkhanchitchai $S$, Tangarunsanti $T$, Jaovisidha S, Nantiruj K, Janwityanujit S. The effect of religious practice on the prevalence of knee Osteoarthritis. Clin Rheumatol 2010;29:39-44.

13. McWilliams D F, Leeb B F, Muthuri S G, Doherty M, Zhang W. Occupational risk factors for osteoarthritis of the knee: a meta-analysis. Osteoarthritis and Cartilage $2011 ; 19: 829-839$.

14. Muraki S, Oka H, Akune $T$, et al. Association of occupational activity with joint space narrowing and osteophytosis in the medial compartment of the knee: the ROAD study. Osteoarthritis and Cartilage 2011; 19:840-846. 